\title{
Correlation Between Maternal Weight Gain During Pregnancy And The Occurrence Of Stunting In Infants
}

Ika Yudianti $^{1^{*}}$

Poltekkes Kemenkes Malang

*ikyudmidwife@gmail.com

Didien Ika Setyarini ${ }^{1}$

Poltekkes Kemenkes Malang

Didien.is@gmail.com

Dini Andriani ${ }^{1}$

Poltekkes Kemenkes Malang

Dini_andriani@ymail.com

\begin{abstract}
Objective: Pregnant women have four categories of BMI, which is underweight, normal, overweight, and obese. Stunting is a growth disorder due to chronic malnutrition which is indicated by the value of $z$ score body length by age less than -2 SD. The impact of stunting in infants and toddlers is cognitive delay in childhood. This study aims to determine the correlation between maternal weight gain during pregnancy with the occurrence of stunting in infants.

Method: The research design uses correlative analytic method with case control approach. Research population were all infants aged $6-12$ months in Tanjungrejo Village, with proportionate stratified random sampling technique. The sample was 69 infants. Data collection tools are infantometer \& mother and child health $(\mathrm{MCH})$ book.

Result: The results of the study indicated that $16 \%$ of stunting respondents with appropriate maternal weight gain, $84 \%$ of stunting respondents with inappropriate maternal weight gain, $45 \%$ of normal respondents with appropriate maternal weight gain and 55\% of normal respondents with inappropriate maternal weight gain. Spearman rank analysis showed that the correlation coefficient between maternal weight gain during pregnancy and stunting occurrence in infants was -0.260 and the significance of $0.031(<0.05)$.

Conclusion: There was a significant correlation of maternal weight gain during pregnancy with the occurrence of stunting in infants. Mothers of infants and the community are expected to fulfill the nutritional needs of pregnant women to gain weight in accordance with pre-pregnancy BMI, thus preventing the occurrence of stunting in infants.
\end{abstract}

Keywords: BMI, prenatal weight gain, stunting.

\section{INTRODUCTION}

Health Research Association in 2013

declared that the national prevalence of short toddlers in 2013 was 37,2 percent, which means an increase compared to $2010(35,6 \%)$ and $2007(36,8 \%)$ [1,2]. This number consists of 18 percent of very short toddlers and 19,2 percent of short toddlers. The prevalence of very short toddler declined from 18,8 percent in 2007 to 18,5 percent in 2010. The prevalence of short toddlers increased from 18 percent in 2007 to 19,2 percent in 2013 [3]. The World Health Organization (WHO) stated that stunting problem is considered severe 
when it reaches 30-39 percent and should be taken seriously if it reaches $\geq 40$ percent of the total toddlers.

Health development program in the period of 2015 - 2019 is focused on four priorities such as reduction of maternal and infant mortality rates, reduction of short toddler prevalence (stunting), control of contagious and non-contagious disease. The target of reduction in the prevalence of stunting in children under two years old is $28 \%$ [4].

In 2015 the Ministry of Health start to implementing Nutritional Status Monitoring (NSM), which is a cross-sectional study with a sample of households with children under five years old in Indonesia. NSM results in 2015 shows that $29 \%$ Indonesian toddlers are categorized as short [4].

Toddlers are individuals aged 0-5 years with the high level of brain plasticity that makes them more open to learn [5]. Toddlers need a good fulfillment of nutrition to support brain development. Toddlers who do not get sufficient nutrition can suffer from stunting. Stunting or short toddler is a condition where the height growth is not in accordance with age. Toddlers with stunting will have an impact on the toddlers themselves. The impact of this condition is an increase in morbidity and disability. Another impact caused by stunting is the decrease of cognitive ability, psychomotor, language and mental in toddlers $[5,6,7]$. Research conducted by Walker in
2008 with the title "Early childhood stunting is associated with poor psychological functioning in late adolescence and effects are reduced by psychosocial stimulation" indicated that children younger than 2 years old who have growth disorder have poor control of emotions and behaviors in their late adolescence.

The occurrence of stunting in toddlers is affected by several factors such as parent's height and maternal nutrient intake during pregnancy [8]. Body height is one of the genetic determinants obtained by children from their parents, while the maternal nutrient intake is associated with maternal weight gain during pregnancy. Research conducted by the Fitrah in 2013 under the title "The Effect of Protein Intake on Pregnant Women and Newborn Length Against the Occurrence of Stunting in Children Aged 12 Months in Bogor" showed that pregnant women with protein intake less than 58 percent RDA have 1,6 times greater risk of having stunting children at the age of 12 months than women with protein intake $\geq 58$ percent RDA. The results of this study indicated that parents have an important role in the growth and development of children, especially nutritional status during pregnancy [9]. Mothers receive more attention in this regard, especially during pregnancy, childbirth, and taking care of the baby until the golden period which is the first a thousand days of life. Mothers should ensure 
that their children get enough nutrition even while they're still in the womb.

Pregnancy is a natural process that occurs in women. This period requires special attention because it is a time of crisis experienced by women. Pregnant women experience a variety of changes in themselves such as physical and psychological changes. One of the physical changes in pregnant women is weight gain. Weight gain is a natural thing, but it is not rare to find a weight loss due to problems in pregnancy $[10,11]$. The ideal weight gain in pregnant women is 6,5 up to $16,5 \mathrm{~kg}$ and an average of $12,5 \mathrm{~kg}[12,13,14]$. If the weight gain is less than the ideal, it will increase the risk of maternal malnutrition, resulting in intrauterine growth retardation (IUGR) and potentially premature labor and intrauterine fetal death (IUFD). Excessive weight gain can also potentially cause pre-eclampsia or eclampsia due to the occurrence of maternal fluid retention. Pregnancy problems can be prevented by doing regular check-ups to the healthcare providers. The minimum number of antenatal care is four times during pregnancy, which is once in the first trimester, once in the second trimester, and twice in third trimester. Antenatal care is done with the hope that mothers can undergo pregnancy so well that babies can be born healthy and grow into healthy infants.

Malang Regional Department of Health in 2016 stated that the prevalence of stunting in Malang is still high. The number of toddlers in Malang is 53.838, $2.394(4,45 \%)$ of them are categorized as short and $687(1,28 \%)$ are categorized as very short. The village with the highest number of stunting is Tanjungrejo Village near Puskesmas Janti with 189 $(8,51 \%)$ short toddlers and $41(1,85 \%)$ very short toddlers out of 2,221. This preliminary study provides the foundation to do a research about correlation between maternal weight gain during pregnancy and the occurrence of stunting in toddlers.

The main objective of this study is to determine the correlation between maternal weight gain during pregnancy with the occurrence of stunting in infants. The specific objectives of this study are to identify maternal weight gain during pregnancy, identify the occurrence of stunting in infants, and analyze the correlation between them.

The results of this study are expected to provide information on the correlation between maternal weight gain during pregnancy and the occurrence of stunting in infants, so that it can be used as preventive action.

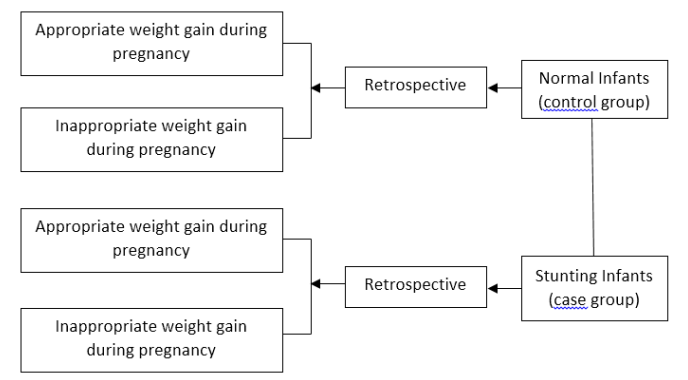




\section{RESEARCH METHOD}

This research uses analytical research methods which is analytical correlative with case control approach to know how far the risk factors can affect it.

The population of this study are infants aged 6-12 months in Tanjungrejo Village in 2016 with the total of 77 infants, divided into 27 infants with stunting and 50 infants without stunting.

The samples were conducted using a sample size for the simple experimental study, which uses the case group and the control group consisting of 25 infants with stunting and 44 normal infants. The samples used were 69 babies. This study uses proportionate stratified random sampling technique.

This study uses two variables, namely:

a. Independent variable

The independent variable in this study is maternal weight gain during pregnancy.

b. Dependent variable

The dependent variable in this study is the incidence of stunting in infants aged 6-12 months.

Inclusion criteria for this study are women in reproductive age who are:

a. Residing in Tanjungrejo Village.

b. Recorded in the local neighborhood health center (posyandu).

c. Has KIA book with complete record of antenatal care during pregnancy.

d. Maternal BMI before pregnancy was normal.
Exclusion criteria for this study are:

a. Infants who suffer from polio.

b. Mothers who had hyperemesis gravidarum or diabetes mellitus during pregnancy.

Table 1. definition variable

\begin{tabular}{|c|c|c|c|c|}
\hline Variable & Definition & $\begin{array}{c}\text { Instrume } \\
\text { nt }\end{array}$ & $\begin{array}{c}\text { Measure } \\
\text { ment } \\
\text { Scale }\end{array}$ & Categories \\
\hline $\begin{array}{l}\text { Maternal } \\
\text { weight } \\
\text { gain } \\
\text { during } \\
\text { pregnancy }\end{array}$ & $\begin{array}{l}\text { The difference } \\
\text { between } \\
\text { mother's body } \\
\text { weight in } 9 \\
\text { months pregnant } \\
\text { (the last } \\
\text { antenatal check- } \\
\text { up result) with } \\
\text { the pre- } \\
\text { pregnancy } \\
\text { weight. }\end{array}$ & $\begin{array}{l}\text { Document } \\
\text { ation } \\
\text { Study }\end{array}$ & Nominal & $\begin{array}{l}\text { a. Appropri } \\
\text { ate for } \\
\text { the BMI } \\
\text { b. Inapprop } \\
\text { riate for } \\
\text { the BMI }\end{array}$ \\
\hline $\begin{array}{l}\text { The } \\
\text { ccurrenc } \\
\text { e of } \\
\text { stunting in } \\
\text { infants } \\
\text { aged 6-12 } \\
\text { months. }\end{array}$ & $\begin{array}{l}\text { Stunting is } \\
\text { defined as the } \\
\text { incompatibility } \\
\text { between height } \\
\text { and age, which is } \\
\text { very short or } \\
\text { short. }\end{array}$ & $\begin{array}{l}\text { Body } \\
\text { length } \\
\text { measurem } \\
\text { ent }\end{array}$ & Ordinal & $\begin{array}{l}\text { a. Very } \\
\text { short : } \\
\mathrm{z} \text { score } \\
<-3,0 \\
\text { b. Short : } \mathrm{z} \\
\text { score } \geq- \\
3,0 \text { up to } \\
\mathrm{z} \quad \text { score } \\
<-2,0 \\
\text { c. Normal : } \\
\mathrm{z} \text { score } \\
\geq-2,0\end{array}$ \\
\hline
\end{tabular}

Data Collection Techniques

1) Looking for the information of potential respondents based on inclusion and exclusion criteria through the community health care center (Puskesmas) data.

2) Explaining to potential respondents about the purposes and objectives of the research.

3) Providing informed consent to the respondents.

4) Doing length measurement to the infants selected as research subjects. 
5) Conducting documentation studies of the antenatal care by looking at the maternal weight before pregnancy to measure BMI and then looking at weight gain during pregnancy and determine whether the weight gain is in accordance with the recommendation based on pre-pregnancy BMI.

6) Noting the body length measurement results and documentation on the observation sheet.

\section{Data Processing Techniques}

After the data were collected, it was processed through the stages as follows:

1) Researcher re-examine the completeness, clarity and appropriateness of the data that has been obtained through the measurement and preliminary studies.

2) The data that has been obtained coded to make the process of tabulation and analysis easy.

3) The encoded data were recapitulated into the master sheet.

4) Data were presented in frequency distribution table based on percentage that was determined using frequency distribution formula.

5) Once the whole data had been collected, the data was processed by using SPSS 16.0 with spearman rank test, due to correlating the scale of nominal and ordinal data.

\section{III.RESULTS}

The following are general data consist of age, height and weight of the respondents.

Table 2. Distribution of Samples According to Body Length

\begin{tabular}{ccccc}
\hline Age & \multicolumn{4}{c}{ Infants } \\
& \multicolumn{2}{c}{ Normal } & \multicolumn{2}{c}{ Stunting } \\
& $\mathrm{f}$ & $(\%)$ & $\mathrm{f}$ & $(\%)$ \\
\hline $6-8$ months & 17 & 39 & 6 & 24 \\
$9-12$ months & 27 & 61 & 19 & 76 \\
Total & 44 & 100 & 25 & 100 \\
\hline
\end{tabular}

Table 2 shows that the majority of respondents with normal body length are infants aged 9-12 months (61\%), while the majority of respondents with stunting are infants aged 912 months (76\%).

Table 3.Distribution of the sample's mother's height

\begin{tabular}{ccccc}
\hline Mother's & \multicolumn{3}{c}{ Infants } \\
Height & \multicolumn{2}{c}{ Normal } & \multicolumn{2}{c}{ Stunting } \\
& $\mathrm{f}$ & $(\%)$ & $\mathrm{f}$ & $(\%)$ \\
\hline $\begin{array}{c}\text { Short } \\
(<145 \mathrm{~cm})\end{array}$ & 4 & 9 & 4 & 16 \\
$\begin{array}{c}\text { Normal } \\
(>145 \mathrm{~cm})\end{array}$ & 40 & 91 & 21 & 84 \\
\hline Total & 44 & 100 & 25 & 100 \\
\hline
\end{tabular}

Table 3 shows that almost all of respondents with normal length had mothers with normal height (91\%), while almost all of stunting respondents had mothers with normal height $(84 \%)$. 
Table 4. Distribution of Samples' Birth

\begin{tabular}{ccccc}
\multicolumn{2}{c}{ Weight } & & \multicolumn{3}{c}{ Infants } \\
& \multicolumn{3}{c}{ Normal } & \multicolumn{2}{c}{ Stunting } \\
& $\mathrm{f}$ & $(\%)$ & $\mathrm{f}$ & $(\%)$ \\
\hline Birth Weight & 2 & 5 & 3 & 7,2 \\
$\begin{array}{c}(<2500 \mathrm{~g}) \\
\text { Normal }(2500- \\
4000 \mathrm{~g})\end{array}$ & 42 & 95 & 22 & 92,8 \\
\hline Total & 44 & 100 & 25 & 100 \\
\hline
\end{tabular}

Table 4 shows that almost all of normal respondents had a history of normal birth weight (95\%), and almost all of stunting respondents had a history of normal birth weight $(92,8 \%)$.

Table 5. Distribution of Maternal Pregnancy Weight Gain

\begin{tabular}{clcc}
\hline No & $\begin{array}{c}\text { Weight Gain } \\
\text { During } \\
\text { Pregnancy }\end{array}$ & $\mathrm{f}$ & $\%$ \\
\hline 1 & $\begin{array}{l}\text { Appropriate for } \\
\text { the BMI }\end{array}$ & 24 & 34,8 \\
2 & $\begin{array}{l}\text { Inappropriate for } \\
\text { the BMI }\end{array}$ & 45 & 65,2 \\
\hline Total & 69 & 100 \\
\hline
\end{tabular}

Table 5 shows that the majority of infants' mothers gained weight during pregnancy that is inappropriate for the BMI $(65,2 \%)$. As many as $78 \%$ of the weight gain is less than the standard weight gain according to BMI, and as much as $22 \%$ more than the standard weight gain according to BMI.
Table 6.Distribution of Stunting in Infants

\begin{tabular}{llll}
\hline No & $\begin{array}{l}\text { Stunting in } \\
\text { Infants }\end{array}$ & $\mathrm{f}$ & $\%$ \\
\hline 1 & $\begin{array}{l}\text { Very Short }(\mathrm{z} \\
\text { score }<-3,0)\end{array}$ & 3 & 4,3 \\
2 & $\begin{array}{l}\text { Short (z } \\
\text { score } \geq-3,0 \\
\text { sampai } \\
\text { dengan z } \\
\text { score }<-2,0)\end{array}$ & 31,9 \\
3 & $\begin{array}{l}\text { Normal (z } \\
\text { score } \geq-2,0)\end{array}$ & 44 & 63,8
\end{tabular}

Total

69

100

Table 6 shows that the majority of infants had normal body length $(63,8 \%)$, a small proportion of infants are short $(31,9 \%)$ and few infants are very short $(4,3 \%)$.

Table 7. Cross Tabulation Between Maternal Weight Gain During Pregnancy and The Occurance of Stunting

\begin{tabular}{ccccccc}
\hline Inappropriate & \multicolumn{5}{c}{ Stunting in Infant } \\
Weight Gain & Very & Short & Normal \\
During & Short & & & & \\
Pregnancy & f & $(\%)$ & $\mathrm{f}$ & $(\%)$ & $\mathrm{f}$ & $(\%)$ \\
\hline Low weight & 1 & 3 & 18 & 51 & 16 & 46 \\
Overweight & 0 & 0 & 2 & 20 & 8 & 80 \\
\hline Total & 1 & 2,2 & 20 & 44,4 & 24 & 53,4 \\
\hline
\end{tabular}

Table 7 shows that almost all mothers with appropriate weight gain during pregnancy have normal length infants $(83,4 \%)$, while mothers with inappropriate weight gain during pregnancy partially have normal length infants 
$(53,4 \%)$ and the rest of them have short infants $(44,4 \%)$.

Table 8. Cross Tabulation Between Inappropriate Maternal Weight Gain with the Occurrence of Stunting

\begin{tabular}{|c|c|c|c|c|c|c|c|c|}
\hline \multirow{3}{*}{$\begin{array}{l}\text { Maternal } \\
\text { Weight } \\
\text { Gain } \\
\text { During } \\
\text { Pregnancy }\end{array}$} & \multicolumn{6}{|c|}{ Stunting in Infants } & \multicolumn{2}{|c|}{ Total } \\
\hline & \multicolumn{2}{|c|}{$\begin{array}{l}\text { Very } \\
\text { Short }\end{array}$} & \multicolumn{2}{|c|}{ Short } & \multicolumn{2}{|c|}{ Normal } & \multirow{2}{*}{$\mathrm{f}$} & \multirow{2}{*}{$(\%)$} \\
\hline & $\mathrm{f}$ & $(\%)$ & $\mathrm{f}$ & $(\%)$ & $\mathrm{f}$ & $(\%)$ & & \\
\hline $\begin{array}{l}\text { Appropria } \\
\text { te }\end{array}$ & 2 & 8,3 & 2 & 8,3 & 20 & 83,4 & 24 & 100 \\
\hline $\begin{array}{l}\text { Inappropri } \\
\text { ate }\end{array}$ & 1 & 2,2 & 20 & 44,4 & 24 & 53,4 & 45 & 100 \\
\hline Total & 3 & 4,3 & 22 & 31,9 & 44 & 63,8 & 69 & 100 \\
\hline
\end{tabular}

Table 8 shows that the majority of women with low weight gain during pregnancy have short infants (51\%), and $46 \%$ of them have normal infants, while almost all of the women with overweight gain during pregnancy have normal infants $(80 \%)$ and a small portion of them have short infants $(20 \%)$.

The result of analysis using Spearman rank test shows that the correlation coefficient between maternal weight gain during pregnancy and the occurrence of stunting in infants is $-0,260$, with the significance of $0,031(<0,05)$ means that there is a significant correlation between maternal weight gain during pregnancy and the occurrence of stunting in infants with low correlation coefficient $(-0,260)$.

\section{IV.DISCUSSION}

Cross tabulation between maternal weight gain during pregnancy with the occurrence of stunting in infants showed that out of the 24 mothers who had appropriate weight gain during pregnancy, $83,4 \%$ of the infants have a normal body length, while out of 45 mothers with inappropriate weight gain during pregnancy most of the infants had normal body length $(53,4 \%)$.

Inappropriate maternal weight gain is divided into categories of low and overweight, the majority of women with low weight gain during pregnancy have short infants (51\%), and $46 \%$ of them have normal infants, while almost all of the women with overweight gain during pregnancy have normal infants $(80 \%)$ and a small portion of them have short infants $(20 \%)$.

Mothers who have low maternal weight gain but the baby has a normal body length is because mothers exclusively breastfed their infants, and pay attention to the complementary feeding for infants. Other than that, the mother's height is categorized as normal. Mother who has overweight maternal weight gain but the baby suffered from stunting is due to mothers being busy working after the baby turned 3 months old and the mother stopped breastfeeding the baby and infant care was taken over by his grandmother. Other than that, the mothers have poor knowledge about nutrition that should be given to the infants, such as the appropriate 
time of giving complementary feeding to the infants.

Factors directly related to the growth and development of infants are micronutrient and macronutrient absorbed by the fetus during gestation. Micronutrients needed by fetus are calcium, iron and folic acid and macronutrient such as carbohydrates, fats, and proteins. This concurs with research conducted by Fitrah in 2013 under the title "The Effect of Protein Intake During Pregnancy and Newborn Length Against the Occurrence of Stunting in Children Aged 12 Months in Bogor" showed that pregnant women with protein intake less than 58 percent RDA have 1,6 times greater risk of having stunting children at the age of 12 months than women with protein intake $\geq$ 58 percent RDA [11]. The results showed that the improvement of macronutrient and micronutrient intake in pregnant women is required to prevent the occurrence of stunting in infants.

Factors that indirectly affects the the correlation between maternal weight gain during pregnancy with the occurrence of stunting in infants are cultural, environmental (sanitation) and socio-economic factor. Data obtained from the WHO in 2005 - 2012 showed that the prevalence of stunting between men and women was higher in poor countries than in developing countries [7]. In poor countries the prevalence of stunting in female was $30 \%$ and in developing countries was $21,1 \%$. The prevalence of stunting in male was $41.7 \%$ in poor countries and $24.1 \%$ in developing countries. The results indicated that the incidence of stunting is influenced by socio-economic and environmental conditions (sanitation).

\section{CONCLUSION}

There is a significant correlation between maternal weight gain during pregnancy with the occurrence of stunting in infants with low correlation coefficient.

\section{REFERENCES}

[1]. Al-anshori, H. Faktor Risiko Kejadin Stunting pada Anak Usia 12 - 24 Bulan. Semarang: Artikel Penelitian Ilmu Gizi Universitas Diponegoro, 2013.

[2]. Arifin, D.Z, Irdasari, S.Y, Sukandar, H. Analisis Sebaran dan Faktor Risiko Stunting pada Balita di Kabupaten Purwakarta. Purwakarta: Artikel Penelitian Dinas Kesehatan Kabupaten Purwakarta, 2012.

[3]. Millennium Challenge Account (MCA) Indonesia. Gambaran Umum Proyek Kesehatan dan Gizi Berbasis Masyarakat (PKGBM) untuk Mencegah Stunting. Available at http://mcaindonesia.go.id/wpcontent/uploads/2013 /12/Buku-Gambaran-Umum-ok.pdf, 2013.

[4]. Kemenkes RI. Keputusan Menteri Kesehatan Republik Indonesia tentang Standar Antropometri Penilaian Status Gizi Anak. Jakarta: Direktorat Bina Gizi, 2010.

[5]. Soetjiningsih. Tumbuh Kembang Anak. Jakarta: EGC, 1995.

[6]. Kusuma, K. E, Nuryanto. Faktor Risiko Kejadian Stunting pada Anak Usia 2 3 Tahun. Journal of Nutrition College, 2013.

[7]. World Health Organization (WHO). Childhood Stunting: Context, Causes, 
and Consequences. WHO Conceptual Framework, 2013.

[8]. McDonald C.M, Manji K.P, Kupka R, Bellinger D.C, Spiegelman D, Kisenge $\mathrm{R}$, et al. Stunting and Wasting are Associated with Poorer Psychomotor and Mental Development in HIVExposed Tanzania Infants. Journal of Nutrition, 2013 Feb;143(2):204-14. doi: 10.3945/jn.112.168682. Epub 2012 Dec 19

[9]. Oktarina, Z. Sudiarti, T. Faktor Risiko Stunting pada Balita (24 - 59 Bulan) di Sumatera. Jurnal Gizi dan Pangan, 2012.

[10]. Arisman. Gizi dalam Daur Kehidupan. Jakarta: EGC, 2004.

[11]. Ernawati, Fitrah. Pengaruh Asupan Protein Ibu Hamil dan Panjang Badan Bayi Baru Lahir terhadap Kejadian Stunting pada Anak Usia 12 Bulan di Kabupaten Bogor. Penelitian Gizi dan Makanan, 2013.

[12]. Prawirohardjo, Sarwono. Ilmu Kebidanan. Jakarta: Yayasan Bina Pustaka, 2009.

[13]. Rukiyah, Ai Yeyeh, dkk. Asuhan Kebidanan I (Kehamilan). Jakarta: CV. Trans Info Media, 2009.

[14]. Sulistyawati, Ari. Asuhan Kebidanan pada Masa Kehamilan. Jakarta: Salemba Medika. 2009. 